\title{
« Blizzard de formulaires officiels », ou la trace du mocassin à l'épreuve de la trace d'encre dans Tracks et Four Souls de Louise Erdrich
}

Elisabeth Bouzonviller

\section{(2) OpenEdition \\ Journals}

Édition électronique

URL : http://journals.openedition.org/elohi/630

ISSN : 2268-5243

\section{Éditeur}

Presses universitaires de Bordeaux

Édition imprimée

Date de publication : 1 janvier 2013

Pagination : 57-77

ISBN : 978-2-86781-899-8

ISSN : $2431-8175$

\section{Référence électronique}

Elisabeth Bouzonviller, « «Blizzard de formulaires officiels », ou la trace du mocassin à l'épreuve de la trace d'encre dans Tracks et Four Souls de Louise Erdrich », ELOHI [En ligne], 3 | 2013, mis en ligne le 01 janvier 2014, consulté le 29 avril 2019. URL : http://journals.openedition.org/elohi/630 


\section{«Blizzard de formulaires officiels », ou la trace du mocassin à l'épreuve de la trace d'encre dans Tracks et Four Souls de Louise Erdrich}

\section{ELISABETH BOUZONVILLER \\ Université Jean Monnet, Saint-Étienne}

Si en 1988 Tracks offrait une sorte d'analepse aux deux premiers romans de Louise Erdrich, seize ans plus tard, Four Souls apportait une suite directe à cette œuvre qui brode à deux voix sur la manière dont Fleur Pillager perd sa terre ${ }^{1}$. Alors que Tracks se clôt sur le départ de Fleur, Four Souls s'ouvre sur son cheminement vengeur vers la ville. La référence au petit chariot qu'elle pousse, rempli de souvenirs de sa forêt volée, assure le lien entre les deux romans (FS 1-2, $T$ 224) ${ }^{2}$. Sur les traces de l'expropriant, Fleur n'a de cesse de se venger et de recouvrer sa terre, ce lieu originel des ancêtres. La dépossession territoriale est donc au centre de ces romans ainsi que le remarque Lorena Stookey quand elle affirme: "Tracks is essentially a story about land - and the lives of the people connected to it - and thus earth is the element Erdrich associates with this novel $»(71)$.

Liant intimement les expériences géographique, tribale et familiale, Erdrich insiste sur l'attachement territorial et déclare: «In a tribal view of the world, where one place has been inhabited for generations, the landscape becomes enlivened by a sense of group and family history " (Wong 43). Le trope de la menace mécanique analysé par Leo Marx trouve évidemment sa place dans cette écriture métisse contemporaine qui, immanquablement, développe le thème de la perte de la terre suite à l'irruption des Blancs. L'industrialisation comme « menace principale à l'image bucolique de l'Amérique» (Marx 26) ne pouvait pas échapper à celle qui rappelle régulièrement dans ses romans que la terre est non

1. Erdrich prévoyait initialement d'écrire une version révisée de Tracks, elle s'est finalement laissée convaincre de ne pas modifier son roman de 1988 et d'en écrire un nouveau (Beidler 56).

2. Nous utiliserons les initiales des romans pour les désigner lors des références: $T$ pour Tracks, FS pour Four Souls, LM pour Love Medicine, TBL pour Tales of Burning Love, PD pour The Plague of Doves et LRM pour The Last Report on the Miracles at Little No Horse. 
seulement un des points de litige essentiels entre les Blancs et les Autochtones mais que sa perte est aussi la cause de nombreuses tragédies individuelles et collectives, ainsi que le développe en particulier son roman de 2008 The Plague of Doves: "I saw that the loss of their land was lodged inside of them forever. This loss would enter me, too. Over time, I came to know that the sorrow was a thing that each of them covered up according to their character [...]

La page titre de Tracks chez Perennial comporte deux empreintes de pas humains à la suite de trois traces de pattes animales. Cette illustration évoque un mode de vie ancestral basé sur la chasse mais est peut-être aussi une allusion à d'autres liens intimes entre humains et animaux quoffre la société anishinaabe, l'empreinte du milieu suggérant même une étape hybride de transformation inattendue entre les deux espèces. Les liens que les Indiens entretiennent avec la nature font partie des clichés longtemps ressassés. Tracks et Four Souls ne font pas exception à cette tradition; ils brodent en effet sur un attachement naturel qui se manifeste parfois même par détranges mutations génétiques entre humains et animaux, ainsi que le suggère cette illustration.

Leo Marx désigne la locomotive comme métaphore principale du trope de «l'idylle interrompue » (27), mais dans Tracks, c'est l'intrusion des forestiers qui menace la terre des ancêtres de Fleur, c'est-à-dire l'Amérique des origines. Mais plus encore que la machine, chez Erdrich, c'est le formulaire, les subtilités administratives, les cartes et hypothèques gérées par des agents peu scrupuleux qui bouleversent l'ordre naturel pérenne des terres indigènes. À l'opposé de ces intrusions mécaniques et administratives, Erdrich célèbre une certaine Amérique des origines où les peuples indigènes respectaient la nature et vivaient en harmonie avec elle. Cependant cette vision pastorale ne reste jamais manichéenne car la société anishinaabe abrite elle aussi violences et traitrises. Résolument moderne, l'Amérique autochtone d'Erdrich dénonce un gâchis écologique et la disparition d'une culture en lien étroit avec la nature mais, dans son approche ambivalente, elle suggère également l'absence d'un idéal de pureté naturelle où l'Indien ferait partie du décor selon le mythe du bon sauvage. Enfin, de l'oralité à la trace écrite, de la trace de mocassin invisible sur la neige aux documents papier, le parcours suivi est celui de la nature à la culture écrite. Histoire de dépossession, histoire de création littéraire, Tracks et Four Souls sont à l'image de l'œuvre d'Erdrich qui inlassablement raconte une Amérique mue par une impulsion pastorale ambiguë qui est aussi impulsion créatrice.

\section{Sauvageries}

Tracks s'organise selon neuf chapitres qui correspondent aux saisons. Depuis l'hiver 1912 jusqu'au printemps 1924, ces marqueurs temporels sont donnés 
successivement en anglais, en anishinaabe, puis en traduction anglaise, par exemple:

\author{
Chapter One \\ Winter 1912 \\ Manitou-geezisohns \\ Little Spirit Sun (T 1)
}

Ainsi, le cycle des saisons semble régir l'agencement de la narration présentée par les deux narrateurs homodiégétiques autochtones (le vieux Nanapush et la jeune métisse Pauline) et présider au destin des personnages. Ce schéma classique liant l'indien et la nature sous-tend le stéréotype du bon sauvage dans le cadre d'une Amérique naturelle, voire édénique. La nature est omniprésente chez cette communauté anishinaabe imaginaire et marque le discours obstinément, de nombreux personnages étant, en particulier, décrits à l'aide de références animales. Les premières lignes du roman offrent une comparaison entre phénomènes naturels et population autochtone, définissant une osmose que le roman ne cessera d'exploiter: "We started dying before the snow, and like the snow, we continued to fall » $(T 1)$. Et Nanapush de poursuivre ses comparaisons naturelles avec une ironie douce-amère:

[...] we thought disaster must surely have spent its force, that disease must have claimed all of the Anishinabe that the earth could hold and bury.

But the earth is limitless and so is luck and so were our people once. (T 1)

Témoin du passage du temps et des transformations imposées à sa communauté, Nanapush tente de raconter à la jeune Lulu l'histoire des siens et surtout de sa mère, Fleur Pillager, dont le prénom n'est qu'une marque parmi tant d'autres de son ancrage naturel et dont le nom présage déjà les dépossessions et saccages ${ }^{3}$. Rescapé des grandes épidémies importées par les Blancs, Nana-

3. Connie A. Jacobs donne un éclairage sur l'origine historique de ce nom qui n'est pas uniquement fictionnel: « [...] the historical Pillagers were known as a belligerent, brave, and fiercely independent group. William Warren says they first received their name in 1781 after occupying Leech Lake where they became known as Pillagers, Muk-im-dua-win-in-e-wug, or 'men who take by force' (256). They earned this name when, in the late 1700s during contact with a sick trader on the lower Mississippi, this group took advantage of the weakened white man's condition and carried off most of his merchandise. The trader fled for his life, as the clan, aroused by liquor and by the excitement of the impending Midéwinin ceremony, 'pillaged' all of his trade goods " (153). Dans un revirement de situation, les Autochtones seront désormais les victimes de la dépossession dont l'idée est contenue dans le patronyme de Fleur. 
push, le vieux sage, a soigné et sauvé Fleur. Il évoque le destin des siens selon un mode élégiaque recourant à la répétition funeste du terme last qui semble annoncer la fin d'une Amérique pastorale et confirmer la théorie courante du $\mathrm{XIX}^{\mathrm{e}}$ et début du $\mathrm{XX}^{\mathrm{e}}$ siècles de la " race en voie de disparition »:

I guided the last buffalo hunt. I saw the last bear shot. I trapped the last beaver with a pelt of more than two years' growth. I spoke aloud the words of the government treaty, and refused to sign the settlement papers that would take away our woods and lake. I axed the last birch that was older than I, and I saved the last Pillager. (T 2)

Dernier élément dans cette liste de destructions naturelles, Fleur est une fois encore l'incarnation d'une nature originelle à l'instar des animaux et des végétaux disparus. Seuls survivants de leur lignée, Fleur et son cousin Moses hantent les bois tels des animaux sauvages. Régulièrement qualifiés par le verbe roam (T 2; FS 26), l'adjectif wild et leur sourire de loup menaçant ${ }^{4}(T 3,23 ; F S$ $3)$, caractéristique des Pillager, selon Pauline (T 19), ils sont les dignes descendants du clan de l'ours (Beidler 291), appartenance symbolisée par quatre ours et une martre gravés sur un morceau de bois (T $5 ; F S 2)$. Un bestiaire fourni alimente l'imagination fertile des focalisateurs internes des deux romans qui ne cessent d'établir des comparaisons plus ou moins effrayantes entre Fleur et son habitat. Elle est tour à tour loup (T 88; FS 73), serpent (FS 44, 192), oiseau de proie ( $T 12 ; F S 19,31,92,203)$, ours (T 12), loutre (T 106; FS 74) et poisson ( $T$ 18) mais aussi arbre et sève ( $T 4,200 ; F S 183)$. Van Dyke indique que c'est le monstre du lac de Matchimanito, Misshepeshu, qui prête ses caractéristiques animales à Fleur et sa lignée et leur confère ainsi un pouvoir de transformation (132-133). À mi-chemin entre l'humain et le naturel ${ }^{5}$, Fleur semble transmettre les paroles des esprits de la forêt: « [...] it was as if the Manitous all through the woods spoke through Fleur, loose, arguing. I recognized them. Turtle's quavering scratch, the Eagle's high shriek, Loon's crazy bitterness, Otter, the howl of Wolf, Bear's low rasp " ( $T$ 59). Vêtue de tons naturels, marron ou vert ( $T$ 18, 22,$34 ; F S$ 2), elle est l'inquiétante fiancée du monstre du lac $(T 11,31)$ capable de survivre mystérieusement à la noyade et d'y entraîner ses ennemis ( $T$ 10): «Her green dress, drenched, wrapped her like a transparent sheet. A skin of

4. Dans Tales of Burning Love, Gerry Nanapush, le petit-fils de Fleur, sévade de prison et, alors qu'il est habilement dissimulé sous un déguisement de femme, seul son "sourire de loup » le rend reconnaissable aux yeux de sa compagne Dot (TBL 175).

5 The Antelope Wife développe plus largement encore cette thématique d'une hybridité entre humain et animal au travers de l'évocation de liens très intimes entre femmes et antilopes ou chevreuils mais aussi de ceux avec des chiens inspirés de la réalité et des mythes de la culture anishinaabe (Bouzonviller 149-151). 
lakeweed » (T 22). Même Eli, son compagnon, s'en trouve effrayé: « Sometimes I woke and her hair was a damp braid tossed against me and once, from along her neck, I picked a curl of black weed from the bottom of the lake» (T 107). Étrange sirène anishinaabe, elle pourrait même porter l'enfant mi-animal de l'homme du lac que ses ancêtres avaient su apprivoiser: "I dreamed how it will look, strange and fearful, bulging eyes, maybe with a split black tail " $(T$ 108, 175). D’ailleurs c'est lors d'une partie de chasse qu'Eli a été séduit par la sauvageonne, le texte entremêlant bien sûr les références féminines à la biche traquée et à Fleur, le chasseur devenant la proie inattendue d'une équipée qui clame la supériorité de la fille des bois (T 41-43). Van Dyke conclut: "She [Fleur] is always the hunter and never the prey, although some of the male characters attempt to be the aggressor " (133). C'est sans doute Pauline, pétrie de culture chrétienne et facilement assaillie d'obsessions diaboliques, qui est la plus encline à opérer des comparaisons ou métaphores animales à propos de Fleur et à s'en affoler. Se souvenant de leurs semaines de travail commun dans une boucherie de la ville voisine, elle a recours au champ lexical de l'animalité pour la décrire:

Fleur's shoulders were broad and curved as a yoke, her hips fishlike, slippery, narrow. An old green dress clung to her waist, worn thin where she sat. Her glossy braids were like the tails of animals, and swung against her when she moved, deliberately, slowly in her work, held in and half-tamed. But only half. I could tell, but the others never noticed. They never looked into her sly brown eyes or noticed her teeth, strong and sharp and very white. Her legs were bare, and since she padded in beadworked moccasins they never saw that her fifth toes were missing ${ }^{6}$. (T 18)

Ses observations rappellent l'illustration de la page titre et ses suggestions de mutations étranges:

She laid the heart of an owl on her tongue so she could see at night, and went out, hunting, not even in her own body. We know for sure because the next morning, in the snow or dust, we followed the tracks of her bare feet and saw where they changed, where the claws sprang out, the pad broadened and pressed into the dirt. By night we heard her chuffing cough, the bear cough. By day her silence and the wide grin she threw to bring down our guard made us frightened. (T 12)

Les références insistantes à ses dents, dans les deux romans, suggèrent une férocité qui se manifeste pleinement quand, dans Four Souls, en route pour la ville, elle dépèce un chien et le dévore (FS 2). Brutalisée par les hommes de la boucherie, Fleur réagit aussi sauvagement que la truie promise à l'abattoir et

6. Je souligne. 
d'ailleurs les souvenirs de Pauline de ces scènes s'ordonnent autour d'un pronom personnel à la troisième personne du féminin qui remplace indifféremment la femme et l'animal, estompant les différenciations d'espèces ( $T$ 25-26). Le cyclone qui fait finalement suite à ces violences est, de l'avis de Pauline, la vengeance évidente de celle qui maitrise la nature (T 26-28). De même, Fleur réussira à retrouver Mauser, l’entrepreneur qui lui a volé ses terres et, dans un premier temps, à le soumettre tel un animal dominé, «I will love you no matter what you do to me, as a dog does. My spirit is meant to be g'dai ${ }^{7}$, your animal, to do as you wish, let live or kill » (FS 46), et Nanapush de conclure: « [...] she never needed any medicine to snag her men. They fell her way like notched trees » (FS 72). À Minneapolis, hors de son cadre naturel, Fleur inquiète. Une parole de travers et l'on risque d'être "étripé " (FS 60), d'ailleurs Polly Elizabeth la nomme "the savage woman " (FS 19) et conscient du danger, Mauser confie à sa belle-sœur: "She came here to skin me $[\ldots]$ ( FS 128).

\section{Pièges}

Jacobs remarque: "Fleur represents the old traditional ways in that she, along with the additionally mythical character Nanapush, calls on her animal helpers and exists as their manifestation " (165-166). Si Nanapush et Fleur sont effectivement les descendants respectifs de familles d'hommes et de femmes médecins aux pouvoirs issus de la nature, les temps ont changé et d'autres forces s'opposent à eux qu'ils ne peuvent contrecarrer avec leurs seuls plantes et savoirs ancestraux. Le diptyque constitué par les deux romans dit clairement le passage de la nature sauvage à l'environnement maîtrisé suite à l'irruption de la machine sur les terres arrachées aux Autochtones par la ruse ou la force. Les deux œuvres constituent les facettes opposées des deux cultures, anishinaabe d'une part et blanche de l'autre. Tracks est situé presque exclusivement en pleine nature et se clôt sur la perte de la terre de Fleur tandis que Four Souls souvre sur son cheminement vers la ville où elle compte se venger. Ce second roman se déroule alternativement à Minneapolis et sur la réserve où Nanapush tente de faire face à une certaine modernité imposée au cadre naturel. Les narrateurs homodiégétiques ne sont plus exclusivement indiens comme dans Tracks puisque les chapitres de Four Souls alternent le point de vue de Nanapush et celui de Polly Elizabeth, la belle-sœur de Mauser, l'entrepreneur fourbe qui a dépossédé Fleur et bien d'autres jeunes Indiennes. En outre, les chapitres ne sont plus désormais ordonnés selon le rythme des saisons mais comportent des titres descriptifs.

7. G'dai signifie ton chien ou animal (Beidler 384). 
Même si, à l'approche de Fleur, la ville semble respirer « comme un gros animal endormi » (FS 3), la nature n'y a pas droit de cité:

A city was raised. Gakaabikaang [Minneapolis]. Place of the falls. Wood framed. Brick by brick. The best brownstone came from an island in the deep cold northern lake called Gichi gami. The ground of the island had once been covered with mammoth basswood that scented the air over the lake, for miles out, with a swimming fragrance of such supernal sweet innocence that those first priests who came to steal Ojibwe souls, penetrating deeper into the heart of the world, cried out not knowing whether God or the devil tempted them. Now the island was stripped of trees. (FS 5)

Fleur, la sauvageonne, s'étonne de cette absence de nature: " The strange lack of plant growth confused her. [...] For a long while she stood before a leafless box hedge, upset into a state of wonder at its square shape, amazed that it should grow in so unusual a fashion, its twigs gnarled in smooth planes » (FS 3). La ville offre le spectacle d'une nature domptée aux étranges formes grotesques qui font écho à la maison de Mauser dont la construction sophistiquée et tourmentée rappelle la maison maudite aux sept pignons de Hawthorne:

High on sloped and snowy grounds, it was unshadowed yet by trees. The roof, gables, porch, all chiseled and bored in fantastic shapes, were frosted with an overnight fall of gleaming snow. Clipped in cones and cubes, the shrubs were coated with the same lacquer, as was the fountain, frozen, and the white cast-iron lacework of the benches and the tea tables in the yard ${ }^{8}$. (FS 11)

Sonorités métalliques des allitérations en [k], formes géométriques, ces arabesques artificielles disent l'emprisonnement et la coercition. La description met en scène la blancheur glacée mortifère d'une demeure bâtie grâce aux arbres de Fleur et autres jeunes Indiennes trompées (FS 6) mais aussi au labeur douloureux des ouvriers immigrants, à l'argent mal acquis et où, précisément, un lynx, rescapé de l'Amérique des origines, fut tué lors du chantier (FS 7-8). Telles des incantations funestes, deux réseaux de répétitions closent ce premier chapitre narré par Nanapush, avec cinq occurrences de "They had this house » et trois de "This house " dévoilant l'envers du décor et annonçant le sinistre destin de ses habitants (FS 8-9). Maison de sang et de larmes, la demeure de Mauser laisse s'écouler une sève qui pleure la perte autochtone:

- all this made of wood, fine-grained, very old-grown, quartersawn oak that still in its season and for many years after would exude beads of thin sap ${ }^{-}$as though

8. Je souligne. 
recalling growth and life on the land belonging to Fleur Pillager and the shores of Matchimanito, beyond. (FS 9)

Mais Erdrich, métisse anishinaabe, française et allemande, n'offre jamais une peinture manichéenne des relations entre Blancs et Autochtones. Certes Fleur est la victime de l'avidité de Mauser mais certains Anishinaabeg se laissent librement séduire par les sirènes de la société de consommation'. Dans la réserve, loin de la vie citadine, Nanapush remarque la faiblesse et la cupidité des siens:

People traded away their land for pianos they couldn't play and bought clothing too fancy for their own everyday use. They bought spoons made of silver when there wasn't food, and gilded picture frames when they had neither pictures nor walls. A strange fancy for zhaaginaash ${ }^{10}$ stuff came over the best of us. (FS 76)

Margaret Kashpaw, la propre compagne de Nanapush, commence par aligner des pierres le long du chemin menant à leur maison et les peint en rose. Pour les Anishinaabeg, les pierres, asiniig (FS 77), sont perçues comme vivantes et représentent les ancêtres ${ }^{11}$. Nanapush estomaqué s'exclame alors avec surprise et ironie: "'Onizhishin"12, I said. For sure, they looked marvelous, so bright in the green scruff and dead leaves. 'You've dressed up our ancestors' " (FS 77). Elle délaisse ensuite les plantations traditionnelles de son jardin pour de nouvelles semences qui offrent finalement une récolte désastreuse (FS 78) et atteint des sommets d'aveuglement et de reniement quand elle se met à rêver au linoléum vu au couvent: "It was far more beautiful than stone, earth, or wood; it was more green than leaves, with drops of cream and ink curled through it " (FS 76). À grand renfort de comparatifs de supériorité, elle tente de convaincre Nanapush et finalement opère en douce, vendant un morceau de terrain appartenant à son fils pour acquérir l'objet de sa convoitise. Bouleversé, Nanapush, qui a cru un moment que les forestiers et leurs machines sétaient indûment appropriés la parcelle (FS 80-81), ne peut croire que celle qu'il célèbre selon de traditionnelles comparaisons animales ait pu ainsi oublier la valeur de la terre: "My sweetheart, my porcupine woman, my prickly dove, had exchanged the

9. Dans Love Medicine, Gerry Nanapush rappelle l'expression désignant les Indiens qui ont oublié les valeurs de leur propre communauté: «[...] an apple [...] red on the outside, white on the inside " (LM 259).

10. Zhaaginaash signifie Blanc (Beidler 395).

11. Erdrich remarque: "The word for stone, asin, is animate. Stones are called grandfathers and grandmothers and are extremely important in Ojibwe philosophy. Once I began to think of stones as animate, I started to wonder whether I was picking up a stone or it was putting itself into my hand " (Beidler 381).

12 Onizhishin signifie joli (Beidler 392). 
real ground for the false ground. My Margaret had betrayed us. She had bought her linoleum and given away Nector's earth » (FS 82).

Habiles chasseurs, Nanapush, Eli et Fleur savent décrypter les traces, traquer le gibier et poser des pièges. Occasionnellement Nanapush piège même les membres de la communauté anishinaabe avec qui il se trouve en conflit; quant à Fleur, elle joue et gagne au poker contre des adversaires qu'elle piège avec l'assurance et le talent qu'elle déploie d'ordinaire en pleine forêt. Cependant, il est des pièges auxquels ces fins chasseurs n’ont jamais été confrontés. L'Indien, qui autrefois posait des pièges destinés aux animaux sauvages, voire à ses ennemis personnels, est maintenant la nouvelle victime piégée ainsi que le comprend Nanapush: "We were snared in laws by then. Pitfalls and loopholes. Attempting to keep what was left of our land was like walking through a landscape of webs » (FS 79). Le danger est même décuplé quand la propre communauté autochtone, voire les intimes, abrite des traîtres à la cause naturelle qui pactisent avec les intrus et leurs machines destructrices. Nanapush, qui sait lire car il a fréquenté lécole des missionnaires jésuites avant de s'en retourner dans les bois ( $T$ 33), pressent la catastrophe mais Fleur, malgré sa sauvagerie effrayante, arbore toute l'innocence naïve du bon sauvage incapable d'envisager le bouleversement de son habitat: "'The land will go,' I told her. 'The land will be sold and measured' » (T 8). La forêt et le lac de Matchimanito, espace labyrinthique maîtrisé par les seuls initiés autochtones (T9), attirent de plus en plus d'intrus blancs qui tentent de leur appliquer des règles géométriques urbaines et d'y faire pénétrer leurs machines:

Every year there are more who come looking for profit, who draw lines across the land with their strings and yellow flags. They disappear sometimes, and now there are so many betting sticks and dice out near Matchimanito at night that you wonder how Fleur sleeps, or if she sleeps at all. (T 9)

L'ère du striage et du quadrillage précède de peu la grande destruction ${ }^{13}$ :

But I watched the wagons take the rutted turnoff to Matchimanito. Few of them returned, it is true, but those that did were enough, loaded high with hard green wood. From where we now sit, granddaughter, I heard the groan and crack, felt the ground tremble as each tree slammed earth. I weakened into an old man as one oak went down, another and another was lost, as a gap formed here, a clearing there, and plain daylight entered ${ }^{14}$. (T 9)

13. Ce même processus de destruction par striation est à l'œuvre dans The Grapes of Wrath de Steinbeck quand le tracteur envahit les terres du Dust Bowl des métayers dépossédés (40-41).

14. Je souligne. 
Humanisés par le verbe groan, les arbres tombent tels des Indiens vaincus et vieillissent prématurément le témoin du carnage. Inversement, Nanapush compare les Indiens à des arbres:

"We Indians are like a forest," I had said once to Damien.

"The trees left standing get more sun, grow thick." (T 184)

Sa famille décimée par l'épidémie entraîne des cauchemars où les humains et les arbres semblent suivre des destins entremêlés qui s'avèrent en fait être, tout à la fois, souvenirs et prémonitions: "I stood in a birch forest of tall straight trees. I was one among many in a shelter of strength and beauty. Suddenly a loud report, thunder, and they toppled down like matchsticks, all flattened around me in an instant. I was the only one left standing " (T 127).

Alors que Fleur dresse sa fine silhouette semblable à un arbre et exhale des effluves boisées ( $T$ 22, 200), Nanapush se dit fait de vieux bois qui brûle aisément ( $T$ 185) et il ploie doucement, tel un "chêne grinçant ", dans les bras enthousiastes de la jeune Lulu ( $T$ 226). La coutume anishinaabe qui, malgré les injonctions des missionnaires, consistait à déposer la dépouille des morts dans les hautes branches de la forêt lie intimement Nanapush et Fleur à ces arbres qui leur murmurent la présence de leurs disparus ( $T$ 15, 163, 177, 210, 220). L'hypallage «bitter oak» ( $T$ 177), qui désigne l'abri du bébé mort né de Fleur, esquisse à la fois l'attachement de Fleur à sa forêt et l'humanité du lieu. Ces figures de style signalent non seulement un ancrage naturel, voire une analogie stéréotypée entre les Autochtones et la nature, mais elles soulignent aussi la possibilité d'une renaissance après le désastre, ainsi David Stirrup conclut: "The tree ultimately becomes a critical metaphor for the undermining of sovereignty, and an emblem of endurance, survival, and resistance " (11).

Dans Tracks et Four Souls, les tropes de la pastorale n'opposent pas systématiquement les Blancs et les Indiens. Erdrich compose une vaste tapisserie où se croisent des restes d'attachement forcené à un mode de vie naturel certes, comme dans le cas de Fleur, mais aussi des adaptations plus ou moins louables au fonctionnement occidental moderne qu'il soit mécanique ou administratif. Bernadette Morrissey, par exemple, entreprend de travailler pour l'agent indien, Tatro, qui gère les parcelles, récolte les impôts et se charge des expropriations, voire des extorsions. Elle défendra ainsi ses biens sans difficultés. Quant au jeune Nector Kashpaw, qui deviendra plus tard fin politicien ( $L M)$, il est finalement responsable de la perte de la terre de Fleur. The Last Report on the Miracles at Little No Horse revient sur une traitrise intimement liée une fois encore à la mécanique. Seul aux commandes d'un autre engin qui commet des ravages, Nector a assis son pouvoir discrètement mais efficacement. Devenu l'utilisateur exclusif de la machine à écrire du bureau de l'agent indien, il finit par détruire 
tous les documents fonciers originaux, promettant ainsi son peuple à la pire des expropriations: "He was now in charge of history, which suited him just fine, and he was only a boy " (LRM 171). Avec sa mère, Margaret, il utilise subrepticement la somme acquise en commun avec Fleur et Nanapush, grâce à la récolte d'écorces aux vertus médicinales ( $T$ 176), pour payer non pas les impôts sur les terres de chacun mais uniquement sur les siennes, entraînant ainsi, à long terme, la saisie du terrain de Fleur ( $T$ 207).

Quand les forestiers débarquent, ils emploient même des Anishinaabe, dont Eli, qui désormais porte les marques vestimentaires de sa soumission aux forces mécaniques des Blancs: «His hair still hung long, held in a tail down his back, but he now wore a new shirt of checkered flannel and his pants were blue and stiff. Thick boots were on his feet " ( $T$ 213). Cette chemise à carreaux typique des Blancs semble proclamer la victoire de la géométrie alors qu'elle annonce un agencement du territoire selon des règles mathématiques qui ont la raideur du jeans et des nouvelles bottes troqués contre la tenue traditionnelle et les mocassins de cuir souple. Le vacarme des chariots et machines n'a alors rien à envier à la métaphore de la locomotive analysée par Leo Marx et signifie clairement le saccage du jardin originel:

Day by day, the rumble of the carts increased and now a barge was operated, pulled along one side of the lake by horses, filled with cut trees. These went to Eli, who worked as a log peeler and lived in a camp constructed on the far shore. Morrisseys and Lazarres worked there too, but never lasted long. (T 217)

Nanapush regrette les ventes forcées et la cupidité mal placée mais ne sait pas comment sopposer au déferlement des forestiers qui, comme les vagues d'immigrants ou les épidémies, se fait toujours plus important:

In the past, some had sold their allotment land for one hundred poundweight of flour. Others, who were desperate to hold on, now urged that we get together and buy back our land, or at least pay a tax and refuse the lumbering money that would sweep the marks of our boundaries off the map like a pattern of straws. Many were determined not to allow the hired surveyors, or even our own people, to enter the deepest bush. They spoke of the guides Hat and Many Women, now dead, who had taken the government pay.

But that spring outsiders went in as before, and some of us too. The purpose was to measure the lake. Only now they walked upon the fresh graves of the Pillagers, crossed death roads to plot out the deepest water where the lake monster, Misshepeshu, hid himself and waited. (T 8)

But no matter how many vanished, more came in their stead, and all of them had crosscut saws, sharp axes, and received for their pay both money and food. (T 217) 


\section{Résistance}

"I salute my grandfather, Patrick Gourneau, and the four branches of the Ojibwa Nation, those of strength, who endure. " (T)

Toujours clairvoyant, Nanapush, qui connaît suffisamment les deux cultures, est lobservateur avisé de cette triste mutation de la communauté anishinaabe et de la transformation du paysage. Si l'absurdité des pierres roses de Margaret pouvait encore attiser son humour, il se défie des aplats de cette même teinte honteuse, semblable à des cicatrices, sur la carte des parcelles autochtones car il sait qu'ils signifient l'arrivée d'intrus à la peau de cette couleur pâle et la perte des terres:

We watched as Damien unfolded and smoothed the map flat upon the table. In the dizzy smell of coffee roasting, of bannock cooking, we examined the lines and circles of the homesteads paid up-Morrisey, Pukwan, Hat, Lazarres everywhere. They were colored green. The lands that were gone out of the tribe - to deaths with no heirs, to sales, to the lumber company - were painted a pale and rotten pink. Those in question, a sharper yellow. At the center of a bright square was Matchimanito, a small blue triangle I could cover with my hand. (T 173)

My concern was the lapping pink, the color of the skin of lumberjacks and bankers, the land we would never walk or hunt, from which our children would be barred. (T 173-174)

Subitement, les terres, lacs et forêts ne sont plus des éléments naturels et les familles des groupes humains solidaires mais uniquement des chiffres, des couleurs discordantes, des lignes et surfaces géométriques ridiculement petites au regard de l'attachement qu'elles impliquent: "We traced the list until we found the names we sought - Pillager, Kashpaw, Nanapush. All were there, figures and numbers, and all impossible. We stared without feeling at the amounts due before summer » ( $T$ 173). Une visite à l'agent indien, que Nanapush accuse dêtre corrompu ( $T$ 208), et le vieil homme comprend que Fleur a perdu sa terre à cause de Nector et Margaret (T 208).

Dans l'esprit de Vine Deloria qui, dans Custer Died for your Sins, ironise sur l'apitoiement que suscitent les Indiens affublés du terme plight (9), Erdrich refuse les stéréotypes et dénonce les pièges administratifs et la traîtrise des Blancs, bien qu'elle ait été critiquée par Leslie Marmon Silko pour sa fiction aux maniérismes post-modernes pas assez engagée politiquement ${ }^{15}$. Sa communauté fic-

15. L. Marmon Silko, "Here's an Odd Artifact for the Fairy-Tale Shelf." Impact Magazine, Albuquerque Journal, (8 October 1986). 10-11. Voir la réaction d'Erdrich à ce sujet (Chavkin 237-238) et les articles de Susan Stanford Friedman, Nancy J. Peterson et Susan Pérez Castillo, par exemple, à propos de cette controverse. 
tionnelle anishinaabe a des ressources infinies. Quand il le faut, elle sait manipuler pièges et vengeances, parfois même selon le mode des Blancs. À la fin de Tracks, Fleur a été dépossédée de sa terre, certes, mais elle subtilise les outils des forestiers et prend de vitesse hommes et machines en sciant partiellement tous ses arbres avant leur arrivée; elle crée ainsi une "forêt suspendue $»^{16}$ ( $T$ 223) qui finalement s'abat sur les envahisseurs sous la pression du vent. La narration offre ainsi une scène cataclysmique rappelant le cyclone d'Argus dont Pauline attribuait déjà la responsabilité à Fleur. Mi-loup mi-sorcière, Fleur, vêtue de rouge et noir, la chevelure illuminée et le sourire féroce (T 221-223) assiste avec jubilation à sa vengeance minutieusement préparée. Hommes et machines sont alors les victimes piégées des hauts chênes que Fleur ne pouvait se résoudre à céder et dont l'humanité se signale dans leur étreinte violente: " [...] they lay mute in the huge embrace of the oaks" (T 224).

De nouveau, dans Four Souls, vengeance et résistance sorganisent selon des schémas empruntés aux Blancs puis détournés. Plutôt que de tuer Mauser, selon son projet initial, Fleur se fait épouser pour redevenir propriétaire de sa terre. Quand les affaires périclitent, Mauser décide de fuir ses créanciers. Fleur, qui refuse de le suivre, obtient la voiture et le titre de propriété de sa terre. Elle revient à la réserve en compagnie de son fils, métis attardé mental, avec l'intention de récupérer sa parcelle mais, une fois encore, les subtilités administratives et fiscales l'ont piégée. Malgré ses visites répétées auprès de l’administration, il est évident qu'elle n’est pas propriétaire car Mauser, comme elle-même autrefois, n’a pas payé ses impôts fonciers et la parcelle a été saisie (FS 185-186). Cependant, bien vite, Nanapush reconnaît dans le comportement de Fleur l'art du chasseur déjà pratiqué sur les employés bouchers autrefois à Argus (FS 186). La voiture, n'est alors plus le symbole blanc de l'intrusion mécanique mais est détournée pour devenir subtil outil de vengeance et de rétablissement d'un ordre bouleversé. Vêtue de blanc dans son luxueux véhicule de même teinte, Fleur rôde, à l'affût, préparant son piège (FS 186): « [...] she needed her land. Signed over, safe, and in her name » (FS 189). C'est finalement au poker, à coup de bluffs sur son apparente faiblesse due à l'alcool et celle de son fils attardé, qu'elle réussit à piéger l'agent indien, Tatro, devenu propriétaire de sa parcelle. Contre la luxueuse voiture ostensiblement exposée sur les routes de la réserve, il accepte de jouer la terre et l'île de Matchimanito et il les perd (FS 196-197), la "voiture fantomatique " (FS 189) devenant ainsi medium qui autorise le retour de Fleur à sa vie naturelle. Blessé dans son orgueil, Tatro prétend ne pas tenir à ce terrain qui ne vaut rien: "'My land is no good anyway.' Fleur gloated 'accor-

16. La traduction française s'est inspirée de cette citation pour le titre du roman, $\mathrm{La}$ Forêt suspendue: «Around me, a forest was suspended, lightly held ( T 223). 
ding to him. Ishkonigan, the leftovers!' The pleasure in her voice was wild " (FS 200). Le terme anishinaabe pour réserve, ishkonigan, est sans équivoque car il signifie également leftovers et desolate lands (Beidler 386) mais malgré ces connotations péjoratives, Fleur et Nanapush connaissent la valeur de ce qu'ils ont réussi à sauver:

I've seen too much go by - unturned grass below my feet, and overhead, the great white cranes flung south forever. I know this. Land is the only thing that lasts life to life. Money burns like tinder, flows off like water. And as for government promises, the wind is steadier. I am a holdout, like the Pillagers, although I told the Captain and the Agent what I thought of their papers in good English. I could have written my name, and much more too, in script. I had a Jesuit education in the halls of Saint John before I ran back to the woods and forgot my prayers ${ }^{17}$. (T 33)

La terre, la nature sont plus puissantes que tout, ainsi que le suggèrent ces comparaisons, néanmoins, à la différence de Fleur la sauvageonne, Nanapush, le vieux conteur, sait aussi la force des mots et le pouvoir de l'écriture. D’autres Anishinaabeg l'ont compris, comme Bernadette Morrissey (T 179) ou Nector Kashpaw $(T 57,207)$ qui savent défendre leurs intérêts auprès de l'administration car ils savent lire et écrire, mais Nanapush, lui, utilise la langue et lécriture dans un subtil mélange politique et littéraire. S'il sait que l'anglais est la langue de la tromperie utilisée dans les traités qui ont subtilisé les terres et sur les étiquettes de bouteilles d'alcool qui déciment les siens ( $T$ 154), s'il a vu que signer un document de son nom équivaut à se faire piéger (T 2, 32, 99-100; FS 79-80), il est néanmoins le narrateur privilégié de Tracks et Four Souls et, pour la fille de Fleur, Lulu, le détenteur de l'histoire familiale et communautaire qu'il tisse au fil de ses récits. Tel Ulysse avec le Cyclope, il prétend avec les Blancs être «Sans Nom » mais quand il s'agit de donner un nom de famille à Lulu $(T 61,178)$ ou de percer les rouages administratifs pour la ramener à la réserve ( $T$ 225), il maîtrise la langue écrite et sait faire usage de son patronyme dans une subtilité à la mesure de sa personnalité:

My girl, listen well. Nanapush is a name that loses power every time that it is written and stored in a government file. That is why I only gave it out once in all those years.

No Name, I told Father Damien when he came to take the church census. No Name, I told the Agent when he made up the tribal roll.

17. Je souligne. 
"I have the use of a white man's name," I told the Captain who delivered the ration payout for our first treaty, "but I won't sign your paper with that name either." (T 32-33)

Le Père Damien, qui n’a rien du missionnaire stéréotypé puisqu'il contribue même à la somme réunie par les trois familles pour éviter la saisie de leurs terres ( $T$ 191), conseille à Nanapush un engagement politique tribal pour défendre les droits des siens, mais dans un premier temps le vieillard recule car, en bon chasseur, il flaire les pièges qui lui seraient tendus:

But I saw the snare right then, the invisible loop hidden in the priest's well-meaning words. Unlike the Pukwans, who were government Indians, I saw the deadfall beneath my feet before I stepped. I would avoid the job. I knew what was attached.

"Wires," I said, "tied to the hands and the arms." (T 185)

Cependant, malgré son dégoût de la paperasserie, il finit par céder dans l'intérêt de Lulu car il comprend la force du crayon et du papier (T 209):

[...] once the bureaucrats sink their barbed pens into the lives of Indians, the paper starts flying, a blizzard of legal forms, a waste of ink by the gallon, a correspondence to which there is no end or reason. That's when I began to see what we were becoming, and the years have borne me out: a tribe of file cabinets and triplicates, a tribe of single-space documents, directives, policy. A tribe of pressed trees. A tribe of chicken-scratch that can be scattered by a wind, diminished to ashes by one struck match.

For I did stand for tribal chairman, as you know, defeating Pukwan in the last year. To become a bureaucrat myself was the only way that I could wade through the letters, the reports, the only place where I could find a ledge to kneel on, to reach through the loophole and draw you home ${ }^{18}$. (T 225)

Lanaphore dit la déception du témoin de la dérive de sa communauté qui a troqué l'arbre pour sa forme industrielle, le papier. Mais plus que le cynique décrypteur des rouages administratifs, Nanapush demeure avant tout le conteur, le narrateur homodiégétique qui retrace la vie de la réserve, pour Lulu dans Tracks, et finalement, pour le lecteur. Dans Four Souls, il n'est pas le témoin direct du séjour de Fleur en ville et avoue: "I pieced together the story " (FS 4). Grand bavard, il est maintenant narrateur et artisan partiel des deux textes que nous livre Erdrich: «I have left my own tracks, too. I have left behind these words » (FS 210). Récepteur des souvenirs de son peuple, il en connaît les souffrances mais aussi les failles et en fait un récit qu'il nous offre à la manière d'un

18. Je souligne. 
vieux sage. Dans Four Souls, en particulier, il rompt régulièrement le cours de l'intrigue et signale son rôle de narrateur-conteur et son travail de manipulation de la langue $(F S 48,58)$ pour finir sur ces mots apaisés: «Within me there has always burned an urge to see how things turn out. To know the story. Now that I know the story, I can rest " (FS 209). Polly Elizabeth, autre narrateur de Four Souls, parcourt un chemin similaire malgré ses préjugés initiaux, elle qui, à la première rencontre avec Fleur, la percevait comme une énigme scripturaire:

I see the negative of her as she stooped to her dark bundle, the image of a question mark set on a page, alone. Or like a keyhole, you could say, sunk into a door locked and painted shut, the deep black figure layered in shawls was more an absence, a slot for a coin, an invitation for the curious, than a woman come to plead for menial work. (FS 12)

De la tradition orale à la trace d'encre, de la trace de pas invisible sur la neige aux preuves papier qui piègent mais peuvent parfois protéger, Nanapush mène le lecteur de la nature à l'écriture. Le cheminement proposé est celui de la littérature comme trace qui se fait mémoire d'un temps qui, sans être idéal, était simplement humain et différent. Si les textes d'Erdrich célèbrent la force d'un attachement à une nature disparue, ils sont aussi chant de la lettre et de la force qu'elle recèle. La parole, le nom et l'écriture mettent finalement un terme à la souffrance de ceux qui regrettent un paradis perdu naturel qui s'avère pourtant n’avoir jamais existé en tant que tel et n’être qu'un stéréotype parmi d'autres. Ainsi, la romancière offre, non pas la nostalgique évocation d'une nature dont la perte serait toujours à venger, mais un appel sage et métissé au souvenir, qui se trouve apaisé par le filtre de la parole et de la littérature. Dans un mouvement métafictionnel, le vieux Nanapush participe non seulement à la reconstruction de vies brisées, comme celles de Fleur ou Lulu, voire celles de sa communauté tout entière, mais il exige aussi l'effort du lecteur qui se voit chargé de recomposer le récit à partir de bribes éparses qui font écho aux distorsions qui ont frappé son peuple: «Fleur left the reservation. Of all that happened day to day, all the ins and outs of her existence, we have what came of the accumulation. We have the story» (FS 74). Nostalgique d'une autre époque, Nanapush rêve de légendes primitives, métaphores d'un mode de vie naturel: "I let myself dream, as I do so often now, of the old days and old people. [...] The winter fires and the aadizokaanag ${ }^{19}$, the stories that branched off and looped back and continued to imitate the flowers on a vine " (FS 114-115). Malgré sa nostalgie, il est l'artisan d'histoires qui, comme celles du passé, s'enroulent et s'entremêlent dans un enchevêtrement infini qui fait appel à l'imagination du lecteur. Ces his-

19. Aadizokaanag signifie mythes, légendes, histoires traditionnelles (Beidler 380). 
toires sauvent ( $T$ 46), réunissent les familles, tissent les liens communautaires ( $T$ 216), aident à comprendre le chemin parcouru ( $T$ 219) et Erdrich invite le lecteur à décrypter ces motifs qui dans un premier temps laissent perplexes ses propres narrateurs homodiégétiques. Au début de Tracks, Nanapush annonce avec sagesse: "There is a story to it the way there is a story to all, never visible while it is happening. Only after, when an old man sits dreaming and talking in his chair, the design springs clear. There was so much we saw and never knew » (T 34). À la fin de Four Souls, Fleur récupère sa terre mais, grâce aux rituels ancestraux de Margaret, elle a aussi accès à un nom secret qui lui donnera identité et force de vie (FS 207). La parole et la terre, telles sont bien les préoccupations de Nanapush, vieux sage éclairé, qui conclut: "This scrap of earth. This ishkonigan. This leftover. We've got this and as long as we can hold on to it we will be some sort of people»(FS 210). Ainsi, il propose au lecteur ce qui est l'ultime essence de toute chose et qui, à l'inverse des arbres et de la terre, ne saurait jamais être volé: "What is the essence, the soul? my Jesuit teachers used to ask of their students. What is the irreducible? I answer, what the owl pukes. That is also the story - what is left after the events in all their juices and chaos are reduced to the essence. The story - all the time does not digest " (FS 71).

Dans Four Souls, Mauser ruiné s'exclame:

The old type, the old warrior type, they are gone. Only the wastrels, the dregs of humanity left, only the poor toms have survived. Even [Fleur] left. I point that out to her. The reservations are ruined spots and may as well be sold off and all trace of their former owners obliterated. That's my theory. Let the Indians drift into the towns and cities or subsist where they will. Thinking their tribes will ever be restored is sheer foolishness. There's nothing left. (FS 127)

Tracks et Four Souls viennent justement s'inscrire en faux contre ce mépris ignorant. Ainsi que le prouvent Fleur et Nanapush, il reste précisément quelque chose: la terre, si pauvre et réduite soit-elle, et la parole dont le pouvoir demeure sans limites. Dans ses interviews, Erdrich insiste d'ailleurs régulièrement sur l'importance des histoires dans sa famille et sa communauté anishinaabe (Chavkin 103-104, 175). Histoires et humour sont deux aspects essentiels de la vie et de la littérature amérindienne contemporaine selon elle (Chavkin 49, 68 ; Coltelli 46). Humour et grotesque pimentent son œuvre qui aurait pu nêtre que nostalgie de l'Amérique naturelle, voire édénique, des peuples autochtones. En outre, même si son écriture peut se faire rappel élégiaque de modes de vie disparus, elle est toujours dénuée de stéréotypes et nuancée par une multitude de références aux forces surnaturelles inquiétantes, parfois même meurtrières, aux vengeances sophistiquées et aux bassesses humaines qui composent également la société anishinaabe de ses romans. La machine a peut-être saccagé le jar- 
din mais elle n'est pas seule responsable, elle est même parfois utilisée comme redresseur de torts. En outre, chez Erdrich, les Blancs ne sont pas tous des envahisseurs avides, comme le prouve le cas du Père Damien ou de Polly Elizabeth.

Bernadette Rigal-Cellard remarque que la question de l'appropriation des terres avait déjà été dénoncée par des auteurs comme Hawthorne ou Faulkner avant même l'émergence d'une littérature autochtone largement concernée par ce sujet (139). Si, comme elle le signale, le culte spécifique de la terre n'existait apparemment pas avant que les Blancs ne tentent de s'en emparer (146), le sujet est cependant devenu central pour des populations et des écrivains profondément marqués par le traumatisme de la perte territoriale. Erdrich adopte en effet ce point de vue dans son article "Where I Ought to Be: A Writer's Sense of Place $»^{20}$ et Stirrup de conclure: "Abstracted and romanticised, this sense of land-attachment and responsibility nevertheless attests to a sense of the temporariness of human societies that figures prominently in other indigenous writing about land» (12). Au-delà d'une position à propos de la terre-mère que certains trouveront peu authentique car le résultat même de la colonisation, se profile donc le sujet crucial de la responsabilité écologique et de la dépossession historique. Quoi qu'il en soit, la terre comme point crucial de l'histoire des relations entre colonisateurs et Autochtones demeure au cour de la littérature amérindienne, ainsi que le souligne Rigal-Cellard: «La fêlure que dénoncent les auteurs indigènes et les autres remonte aux origines des États-Unis au hiatus coupant pour toujours une vision paradisiaque du continent de la réalité d'un peuplement forcément destructeur » (205). Cette prépondérance de la dépossession dans la littérature autochtone est mise en avant par Erdrich elle-même quand elle insiste sur une notion de perte qui ne se résume pas nécessairement à la terre mais peut être élargie à la culture en général: "Contemporary Native American writers have therefore a task quite different from that of other writers I've mentioned. In the light of enormous loss, they must tell the stories of contemporary survivors while protecting and celebrating the cores of cultures left in the wake of the catastrophe " (Wong 48).

Selon le vieux Nanapush, les Anishinaabeg ne laissaient autrefois « aucune trace »:

20. « $[\ldots]$ although fiction alone may lack the power to head us off the course of destruction, it affects us as individuals and can spur us to treat the earth [...] as we would treat our own mothers and fathers. For, once we no longer live beneath our mother's heart, it is the earth with which we form the same dependent relationship, relying completely on its cycle and elements, helpless without its protective embrace" (Wong 50). 
Once we were a people who left no tracks. Now we are different. We print ourselves deeply on the earth. We build roads. The ruts and skids of our wheels bite deep and the bush recedes. We make foundations for our buildings and sink wells beside our houses. Our shoes are hard and where we go it is easy to follow. (FS 210)

Si les bottes ont remplacé les mocassins, si les routes se substituent aux sentiers forestiers, il est cependant des traces que le vieux conteur avide d'histoires ne saurait regretter, celle de l'écriture. De l'oralité à la trace d'encre, Erdrich offre un métissage fictionnel qui ouvre la société anishinaabe à une certaine modernité. Finalement, Tracks et Four Souls proposent un cheminement subtil qui part des traces naturelles de la forêt, se poursuit avec les pièges en tous genres des Blancs mais aussi des Indiens pour se terminer sur l'essentiel, ce qui reste quand la chouette vomit, dirait Nanapush, la littérature (FS 71).

\section{Bibliographie}

Beidler, Peter G. et BArton, Gay. A Reader's Guide to the Novels of Louise Erdrich. Columbia: University of Missouri Press, 2006.

Bouzonviller, Elisabeth. "Cracks and 'Bricolage' in Louise Erdrich's The Antelope Wife or the Art of Hybridity." Guignery V., Pesso-Miquel C. et Specq F., eds., Hybridity: Forms and Figures in Literature and the Visual Arts. Newcastle: Cambridge Scholars Publishing, 2011. 147-157.

Chavkin, Allan et Feyl Chavkin, Nancy. Conversations with Louise Erdrich and Michael Dorris. Jackson: University Press of Mississippi, 1994.

Coltelli, Laura. Winged Words: American Indian Writers Speak. Lincoln: University of Nebraska Press, 1990.

Deloria, Vine, Jr. Custer Died for your Sins: An Indian Manifesto. New York: Avon Books, 1972 [1969].

Erdrich, Louise. Love Medicine. New York: Bantam Books, 1987 [1984]. The Beet Queen. New York: Bantam Books, 1987 [1986]. Tracks. New York: Harper Perennial, 1989 [1988]. Tales of Burning Love. New York: Harper Perennial, 1997 [1996].

The Antelope Wife. New York: Harper Perennial, 1999 [1998]. The Last Report on the Miracles at Little No Horse. New York: Harper Perennial, 2002 [2001].

Four Souls. New York: Harper Perennial, 2006 [2004]. The Plague of Doves. New York: Harper Perennial, 2008. La Forêt suspendue. Paris: Laffont, 1990. 
"Where I Ought to Be: A Writer's Sense of Place." Wong H. D. Sweet, ed., Louise Erdrich's Love Medecine: A Casebook. New York: Oxford University Press, 2000. 43-50.

Hawthorne, Nathaniel. The House of the Seven Gables. Mineola: Dover Publications, 1999 [1851].

Jacobs, Connie A..The Novels of Louise Erdrich: Stories of her People. New York: Peter Lang, 2001.

Marx, Leo. The Machine in the Garden: Technology and the Pastoral Ideal in America. New York: Oxford University Press, 1964.

Pérez Castillo, Susan. "Postmodernism, Native American Literature and the Real: The Silko-Erdrich Controversy." Amherst: The Massachusetts Review 32. 2, (Summer 1991). 285-294.

Peterson, Nancy J.. "History, Postmodernism, and Louise Erdrich's Tracks." New York: Modern Language Association 109. 5, (October 1995). 982-994.

Rigal-Cellard, Bernadette. Le Mythe et la plume. La littérature indienne contemporaine en Amérique du Nord. Monaco : Éditions du Rocher, 2004.

SiLKo, Leslie Marmon. "Here's an Odd Artifact for the Fairy-Tale Shelf." Impact Magazine, Albuquerque Journal, (8 octobre 1986). 10-11.

Stanford Friedman, Susan. "Identity Politics, Syncretism, Catholicism, and Anishinabe Religion in Louise Erdrich's Tracks." Religion and Literature. South Bend: The University of Notre Dame 26. 1, (Spring 1994). 107-133.

Steinbeck, John. The Grapes of Wrath. New York: Penguin, 1997 [1939].

StirRup, David. Louise Erdrich. Manchester and New York: Manchester University Press, coll. "Contemporary American and Canadian Writers », 2010.

Stookey, Lorena L.. Louise Erdrich: A Critical Companion. Westport: Greenwood Press, 1999.

Van Dyke, Annette. "Of Vision Quests and Spirit Guardians: Female Power in the Novels of Louise Erdrich." Chavkin Allan, ed., The Chippewa Landscape of Louise Erdrich. Tuscaloosa: University of Alabama Press, 1999. 130-143.

Résumé : Les liens que les Indiens entretiennent avec la nature font partie des clichés longtemps ressassés. Cependant, tandis que la romancière amérindienne Louise Erdrich célèbre une certaine Amérique des origines où les peuples indigènes respectaient la nature et vivaient en harmonie avec elle, cette vision pastorale n'est pour elle jamais manichéenne car les individus ont leurs spécificités. Résolument moderne, l'Amérique autochtone d'Erdrich, dénonce un gâchis écologique et la disparition d'une culture en lien étroit avec la nature mais elle suggère aussi l'absence d'un idéal de pureté naturelle où l'Indien ferait partie du décor selon le mythe du bon sauvage. Dans cet article centré sur les romans Tracks (1988) et Four Souls (2004), nous mettons en relief son approche nuancée de la pastorale indigène. Si la fiction d'Erdrich montre la force d'un attachement à une nature disparue, elle est aussi chant de la lettre et de la force qu'elle recèle. Ainsi, Erdrich offre non pas la nostalgique évocation d'une nature dont la perte serait à venger mais un appel sage et résilient au souvenir, qui se trouve apaisé par le filtre de la parole et de la littérature. 
Mots-clés : Erdrich, Tracks, Four Souls, littérature amérindienne, Amérique, Dakota du Nord, Indiens, Autochtones, Anishinaabeg, colonisation, forêt, terre, dépossession, machine, conteur, histoires.

Elisabeth Bouzonviller est maître de conférences à I'Université Jean Monnet de St-Etienne où elle enseigne la littérature et la civilisation américaines depuis 1999. Spécialiste de F. Scott Fitzgerald, elle a publié le titre consacré à cet auteur chez Belin dans la collection «Voix américaines ». Membre de la F. Scott Fitzgerald Society basée à Hofstra University, New York, elle fait partie du comité de lecture de la F. Scott Fitzgerald Review où elle publie régulièrement articles et recensions. Elle a participé à plusieurs émissions radiophoniques nationales sur les Fitzgerald. Elle a contribué au recueil A Distant Drummer: Foreign Perspectives on F. Scott Fitzgerald publié en 2007 chez Peter Lang et à l'ouvrage américain F. Scott Fitzgerald in Context à paraître en mars 2013 chez Cambridge University Press. Elle a écrit divers articles sur des romanciers américains du XXe siècle (Faulkner, Hemingway, Steinbeck) et s'est consacrée, plus récemment, à une recherche littéraire tournée vers l'indianité avec des articles et communications consacrés à Emily Carr, N. Scott Momaday et surtout Louise Erdrich, ses dernières publications dans ce domaine faisant partie des recueils De la Peur en Amérique : I'Amérique au défi du frisson (2010), Fiction, Crime and the Feminine (2011) et Hybridity: Forms and Figures in Literature and the Visual Arts (2011).

Summary : The links between Native Americans and nature are part of long-lived clichés. If American novelist Louise Erdrich celebrates a primeval America where indigenous people lived indeed in harmony with nature, her pastoral vision is never Manichean because individuals always behave in their own personal ways. Her Native America is definitely modern and while it denounces an ecological mess and the disappearance of indigenous cultures much attached to their natural habitats, it also rejects an ideal vision in which the Natives were part of a unspoiled setting along the "Noble savage" myth. In this article, we focus on Tracks (1988) and Four Souls (2004) and stress the various nuances of her approach of the indigenous pastoral myth. Whereas Erdrich's fiction shows the power of attachment to a lost natural America, it also emphasizes the importance of words and memory. Thus, she does not express a form of nostalgia implying a desire for revenge for this violent dispossession due to colonization but suggests survival and resilience thanks to her wise appeal to memory through story-telling and literature.

Keywords : Erdrich, Tracks, Four Souls, Native American writing, America, North Dakota, Indians, Natives, Anishinaabeg, colonization, forest, land, dispossession, machine, story-telling.

Elisabeth Bouzonviller is Associate Professor at Jean Monnet University in St Etienne, France, where she has been teaching American literature and culture since 1999. She published Francis Francis Scott Fitzgerald, écrivain du déséquilibre in the Belin collection "Voix américaines" in 2000. She is a member of the F. Scott Fitzgerald Society and has published various articles and reviews in its Review. She has taken part in several French national radio programs devoted to the Fitzgeralds. She contributed to $A$ Distant Drummer: Foreign Perspectives on F. Scott Fitzgerald published in 2007 by Peter Lang and also to F. Scott Fitzgerald in Context to be published in March 2013 by Cambridge University Press. She has contributed to other collected works with articles on Fitzgerald but also on Hemingway, Faulkner or Steinbeck. She is currently working on Native American writers, especially Louise Erdrich whose novels she has dealt with in recent collective publications such as De la Peur en Amérique : I'Amérique au défi du frisson (2010), Fiction, Crime and the Feminine (2011) et Hybridity : Forms and Figures in Literature and the Visual Arts (2011). 